\title{
PENERAPAN PEMBELAJARAN KONTEKSTUAL UNTUK MENINGKATKAN BERPIKIR KRITIS MAHASISWA PADA MATA KULIAH ANTROPOLOGI PARIWISATA
}

\author{
Daniel Harapan Parlindungan Simanjuntak*, Payerli Pasaribu*, Waston Malau*, Tumpal Simarmata* \\ Staf Pengajar di Prodi. Pendidikan Antropologi Fakultas Ilmu Sosial Universitas Negeri Medan
}

\begin{abstract}
Abstrak
Artikel ini merupakan hasil dari penelitian mengenai implementasi pembelajaran kontekstual untuk meningkatkan berfikir kritis mahasiswa pada mata kuliah Antropologi Pariwisata. Pemilihan model pembelajaran di masing-masing mata kuliah diharapkan dapat mengembangan pemikiran kritis mahasiswa dalam menyikapi berbagai permasalahan di masyarakat. Pembelajaran kontekstual dalam pembelajaran Antropologi Pariwisata mampu meningkatan berfikir kritis mahasiswa. Penerapan enam penugasan dalam model pembelajaran kontekstual pada mata kuliah Antropologi Pariwisata dapat membantu merangsang peningkatan berfikir kritis mahasiswa. Berfikir kritis mahasiswa yang dimaksud dalam tulisan ini dapat dilihat berupa artikel ilmiah yang dibuat oleh mahasiswa. Mahasiswa berfikir kritis tentang kondisi pariwisata dan kendala yang dihadapkan pariwisata di kota Medan serta memberikan ide-ide sebagai upaya merekayasa solusi untuk pengembangan kepariwisataan di kota Medan khususnya.
\end{abstract}

Kata Kunci: Model Pembelajaran, Berfikir Kritis, Pariwisata, Pengembangan Kepariwisataan

\section{PENDAHULUAN}

$21^{\text {st }}$ century atau dikenal dengan abad 21 yang sedang berlangsung tentunya memiliki karakteristik tersendiri dibanding abda-abad sebelumnya ataupun sesudahnya. Ketergantungan terhadap teknologi dan internet menjadi salah satu karakteristiknya. Dampak positif dan negatif mengikuti perkembangan teknologi dan internet pada masa ini. Sehingga berpikir kritis menjadi salah satu kemampuan yang diperlukan oleh individu di masa $21^{\text {st }}$ century. Pariwisata merupakan salah satu industri yang terdampak oleh perkembangan teknologi dan internet. Persaingan bidang pariwisata mendorong setiap negara untuk menggunakan teknologi dan internet sebagai bagian dalam pengembangan pariwisatanya. Penelitian ini diharapkan tidak hanya membantu mahasiswa meningkatkan kemampuan berpikir kritis yang dapat digunakan dalam kehidupan sehari-hari namun juga dapat mendorong mahasiswa untuk memiliki ketertarikan dalam pengembangan pariwisata khususnya di Sumatera Utara.

Pariwisata telah menjadi salah satu industri terbesar di dunia, dan merupakan andalan utama dalam menghasilkan devisa di berbagai Negara, salah satunya di Indonesia. Negara-negara seperti Thailand, Singapore, Filipina, Fiji, Maladewa, Hawaii, Tonga, Galapagos, Barbados, Kepulauan karibia dan sebagainya, sangat tergantung pada devisa yang didapatkan dari kedatangan wisatawan. Salah satu contohnya adalah di kepulauan Karibia, pariwisata merupakan penyumbang terbesar dalam penciptaan pendapatan masyarakat dan Negara. 2,5 juta kesempatan kerja atau sekitar $25 \%$ dari total kesempatan kerja pada tahun 2001 (Monsen, 2004 dalam Pitana dan Gayatri, 2005). Sehingga bisa dibayangkan, bagaimana sebuah industri pariwisata sedemikian besar menanggulangi pengangguran di Negara tersebut. Bahkan tidak hanya itu saja, pariwisata juga menyumbang US\$ 9,2 milyar atau 5,8\% dari total GDP di Negara tersebut, sehingga apabla diprediksikan pada tahun 2011 akan menghasilkan penerimaan sekitar US\$ 18,7 milyar (Duval, 2004 dalam Pitana dan Gayatri 2005). Sebuah peningkatan yang sangat signifikan hampir $100 \%$.

Bagi Negara Indonesia sendiri, peranan pariwisata semakin terasa, terutama setelah melemahnya peranan minyak dan gas. Walaupun nilai nominalnya dalam dolar sedikit mengalami fluktuasi. Kunjungan wisatawan mancanegara menunjukkan trend naik dalam erapa dasawarsa. Tahun 1969, Indonesia hanya dikunjungi oleh 6.067 wisman, kemudian meningkat menjadi 2.051.686 tahun 1990, dan 5.064.217 tahun 2000. Sejak 1969, jumlah kunjungan wisman hanya mengalami pertumbuhan negative sebanyak empat kali, yaitu tahun 1982, 1998, 1999, dan 2001. Kedatangan wisman tersebut telah memberikan penerimaan devisa yang sangat besar kepada Indonesia. Devisa yang diterima secara berturut-turut pada tahun 1996, 1997, 1998, 1999 dan 2000 adalah sebesar 6,037.69; 5,321.46; $4,331.09 ; 4,710.22$; dan $5,748.80$ juta dollar AS (Santosa, 2001 dalam Pitana dan Gayatri 2005).

Bagi Indonesia, terutama Bali sekarang ini sudah sangat terkenal sebagai "surga pariwisata" bagi salah satu tujuan wisata dunia, maka peranan industri perpelancongan ini dalam pembangunan di Indonesia tidak perlu lagi dipertanyakan. Hal ini dikarenakan salah satunya adalah Bali tidak terdapat sumber daya alam seperti migas, hasil hutan, ataupun industri manufacture yang berskala besar, maka pariwisatalah yang menjadi sektor andalan. Dari segi pendapatan pemerintah, pariwisata merupakan sumber pendapatan asli daerah yang sangat besar peranannya dalam pembangunan Bali. Pada tahun 1999/2000, jumlahnya yang dihasilkan dari seluruh kabupaten/kota di Bali mencapai 299,853 Milyar rupiah. Daari segi ketenagakerjaan, pada tahun 1995, pariwisata menyerap 34,14\% dari seluruh tenaga kerja yagn bekerja di bali. Persentase ini terus naik, dan 
pada tahun 1998 mencapai 38,0\%. (Pitana dan Gayatri, 2005).

Demikianlah peranan pariwisata dalam pembangunan ekonomi sudah sangat jelas dari paparan tersebut di atas. Tetapi yang perlu diingat adalah pariwisata bukan hanya masalah ekonomi, melainkan juga masalah social, budaya, politik dan seterusnya. Sebagai sebuah aktivitas yang begitu besar pengaruhnya terhadap kehidupan manusia, pariwisata telah banyak menarik minat dari berbagai disiplin ilmu untuk mengkajinya, salah satunya adalah Antropologi Pariwisata. Walaupun tidak bisa dipungkiri bahwa pada awalnya lebih dipandang sebagai kegiatan ekonomi dan tujuan utama pengembangan pariwisata adalah untuk mendapatkan keuntungan ekonomi, baik bagi masyarakat maupun daerah (Negara), akan tetapi dampak yang terjadi begitu hebat dan global, sehingga penting untuk dikaji.

Begitu luasnya aspek yang termasuk dalam pariwisata, menyebabkan begitu banyaknya hal-hal yang memerlukan kajian bagi antropologi. Dari banyaknya aspek yang dapat dikaji, maka Antropologi Pariwisata mengelompokannya ke dalam empat wilayah kajian, yaitu: wisatawan itu sendiri, hubungan antara wisatawan dengan masyarakat local, struktur dan fungsi system pariwisata dan dampak-dampak pariwisata. Dengan begitu banyakya kajian yang harus dikuasai oleh mahasiswa dalam belajar pembelajaran di Program Studi Pendidikan Antropologi semester 3 (semester ganjil) dengan beban kuliah 3 SKS, maka bagaimana upaya kita untuk mengimplementasikan metode pembelajaran kontekstual untuk menumbuhkan daya berpikir kritis mahasiswa. Artinya mahasiswa menerapkannya langsung kepada konteksnya yaitu: wisatawan itu sendiri, hubungan antara wisatawan dengan masyarakat local, struktur dan fungsi system pariwisata dan dampak-dampak pariwisata, sehingga mahasiswa bisa berpikir dengan kritis tentang banyak hal. Di sinilah mahasiswa mencoba dituntun untuk bagaimana 2 nilai yang bertemu antara pendatang dan local, sehingga tidak terjadi benturan dengan nilai-nilai yang diinginkan oleh wisatawan. Bagaimana bentuk dari objek wisata yang diinginkan oleh wisatawan, sehingga laku bagi tourism. Bagaimana sikap warga masyarakat terhadap wisatawan yang datang dan terakhir adalah adanya satu pemikiran kritis untuk meminimalisir dampak yang muncul dari pariwisata yang memang sudqah pasti muncul.

Berdasarkan hasil pengamatan awal, dalam pembelajaran, peserta didik umumnya masih menganggap bahwa materi antropologi pariwisata terkesan sebagai mata kuliah yang hanya pengisi waktu luang, waktu bersenang-senang (lesure time), pergi melancong ke tempat-tempat wisata, gaya hidup dan belanja (konsumerisme). Hal ini membuat peserta didik menjadi kurang kritis dalam berfikir dan beragam problema yang sebetulnya saling mengait akan tetapi kurang tertangkap sebagai bahan mata kuliah yang bermakna.

Persoalan tersebut memunculkan dilema tersendiri pada tingkat pembelajaran yang seharusnya peserta didik sudah memasuki fase akademik yang diwujudkan dengan analisa dan pemantapan wacana melalui kepenulisan laporan. Untuk menjembatani persoalan ini, model pembelajaran seharusnya diubah ke arah pola yang lebih aktif. Apabila mengacu pada pembelajaran dengan model Contextual Teaching and Learning (CTL), maka perlu satu strategi terasa lebih relevan untuk diciptakan. Sebuah strategi yang bertujuan untuk penumbuhkan daya berpikir kritis mahasiswa dalam segala hal, yang nantinya bisa digunakan tidak hanya pada mata kuliah antropologi pariwisata saja.

Permasalahan pokok dalam penelitian ini adalah cara menumbuhkan berfikir kritis pada mahasiswa Antropologi, sehingga dapat dirumuskan dalam tiga pertanyaan sebagai berikut:

1. Bagaimana bentuk disain pendidikan kontekstual dan penerapannya pada kajian antropologi pariwisata?

2. Apakah penerapan pendekatan kontekstual dapat menumbuhkan daya berfikir kritis pada mahasiswa?

3. Seberapa jauh pendekatan kontekstual mampu menumbuhkan daya berfikir kritis pada mahasiswa?

\section{Kajian Kepariwisataan dalam Antropologi} Pariwisata

Pariwisata memang pertama-tama adalah pengembangan dari ekonomi, memasarkan pemandangan dan hasil budaya manusia, mengubah kawasan-kawasan dan masyarakat-masyarakat dunia menjadi produk wisata. Namun di balik kegiatan memasarkan dunia ini sesungguhnya berlangsung proses lain, yang menyangkut jati diri bangsa dan makna-makna baru dalam identitas budaya.

Perkembangan kepariwisataan juga karena adanya pergerakan manusia di dalam mencari sesuatu yang belum diketahuinya, menjelajahi wilayah yang baru, mencari perubahan suasana ataupun untuk mendapatkan sebuah perjalanan baru. Akan tetapi sesungguhnya bahwa pariwisata telah dimulai sejak dimulainya peradaban manusia itu sendiri, ditandai oleh adanya pergerakan manusia yang modern, tonggaktonggak bersejarah dalam pariwisata dapat ditelusuri dari perjalanan Marcopolo (1254 - 1324) yang menjelajahi Eropa, sampai ke Tiongkok, untuk kemudian kembali ke Venesia. Kemudian disusul oleh Pangeran Henry (1394 - 1460), Christopher Colombus (1451 - 1506), dan Vasco Da Gama (akhir abad XV). Namun, sebagai kegiatan ekonomi, pariwisata baru berkembang pada awal abad 19; dan sebagai industri internasional pariwisata dimulai tahun 1869 (Pitana dan Gayatri, 2005).

Bagi Indonesia, jejak pariwisata dapat ditelusuri kembali pada dasa warsa awal abad 20 (tepatnya 1910), yang ditandai dengan dibentuknya VTV (Vereeneging Toeristen Verker), sebuah badan pariwisata Belanda, berkedudukan di Batavia. Badan pemerintah ini juga sekaligus bertindak sebagai tour operator dan travel 
agent, yang secara gencar mempromosikan Indonesia (khususnya Jawa kemudia Bali). Pada tahun 1926 berdiri pula di Jakarta sebuah cabang dari Lislind (Lissome Lindeman) yang pada 1928 berubah menjadi Nitour (Nederlandsche Indische Touriten Bureau), sebagai anak perusahaan dari perusahaaan pelayaran Belanda (KPM). KPM secara rutin melayani pelayaran yang menghubungkan Batavia, Surabaya, Bali dan Makasar, dengan mengangkut wisata (Picard, 2006).

Setelah Indonesia merdeka, pada tahun 1946 pemerintah membentuk Honet (Hotel National and Tourism), sebuah badan yang diberikan tugas untuk menghidupkan kembali pariwisata, khususnya menangani perusahaan-perusahaan Belanda. Pada tahun 1955 berdiri Natour dan YTI (Yayasan Turisme Indonesia). Dengan usaha yang keras, badan-badan ini berhasil mengangkat pariwisata Indonesia, sehingga sempat terjadi demam pariwisata beberapa tahun lamanya. Kongres I YTI, 12 - 14 Januari 1957 (disebut pula Munas Tourisme I) melahirkan Dewan Tourisme Indonesia (DTI). Istilah pariwisata sendiri lahir belakangan, dimana pariwisata diartikan sebagai Internstional Tourism, sedangkan untuk Domestic Tourism dipopulerkan istilah dharma wisata. Menyadari besarnya potensi pariwisata Indonesia, Presiden Soeharto dalam pengarahannya kepada Bapparnas, 26 Januari 1985, bahkan mengharapkan agar sektor ini mampu menjadi penghasil devisa kedua, atau sekurangkurangnya ketiga. (Pitana, 2005)

Meskipun pariwisata telah lama mejadi perhatian, baik dari segi ekonomi, politik. administrasi kenegaraan, maupun sosiologis dan antropologis, sampai saat ini belum ada kesepakatan secara akademis mengenai apa itu wisatawan dan pariwisata. Kata wisata (tour) secara harafiah dalam kamus berarti "perjalanan dimana si pelaku kembali ke tempat awalnya; perjalanan sirkuler yang dilakukan untuk tujuan bisnis, bersenang-senang, atau pendidikan, pada mana berbagai tempat dikunjungi dan biasanya menggunakan jadwal perjalanan yang terencana". Batasan ini mempunyai ruang yang sangat luas, karena berbagai motivasi termasuk di dalamnya, sehingga sulit melakukan pengukuran.

Orang yang melakukan perjalanan wisata disebut wisatawan atau tourist. Batasan terhadap wisatawan juga sangat bervariasi, mulai dari yang umum sampai dengan yang sangat teknis spesifik. United Nation Conference On Travel and Tourism di Roma memberikan batasasn yang lebih umum, tetapi dengan menggunakan istilah visitor (pengunjung), yaitu bahwa setiap orang yang mengunjungi Negara yang bukan merupakan tempat tinggalnya, untuk berbagai tujuan tetapi bukan untuk mencari pekerjaan atau penghidupan dari Negara yang dikunjungi.

Meskipun ada variasi batasan mengenai pariwisata, ada beberapa komponen pokok yang secara umum disepakati di dalam memberikan batasan mengenai pariwisata, khusunya pariwisata internasional, yaitu sebagai berikut:

1. Traveler, yaitu orang yang melakukan perjalanan antar dua atau lebih lokalitas
2. Visitor, yaitu orang yang melakukan perjalanan ke daerah yang bukan merupakan tempat tinggalnya, kurang dari 12 bulan dan tujuan perjalanannya bukanlah untuk terlibat dalam kegiatan untuk mencari nafkah, pendapatan atau penghidupan di tempat tujuan.

3. Tourist, yaitu bagian dari visitor yang menghabiskan waktu paling tidak satu malam (24 jam) di daerah yang dikunjungi (WTO, 1995)

Ada beberapa hal pokok yang pokok dari defenisi yang mengemukakn tentang pariwisata, meskipun berbeda dalam penekanannya adalah sebagai berikut:

1. a dynamic element, yaitu travel ke suatu destinasi wisata

2. a static element, yaitu singgah di daerah tertentu

3. a consequential element, atau akibat dari dua hal di atas (khususnya pada masyarkat local), yang meliputi dampak ekonomi, sosial, dan fisik dari adanya kontak dengan wisatawan.

\section{Konsep Pembelajaran Kontekstual}

Kata contextual berasal dari kata context yang berarti hubungan konteks, suasana dan keadaan (konteks)". (KUBI, 2002; 519) Dengan demikian dapat diartikan sebagai suatu pembelajaran yang berhubungan dengan suasana tertentu. Secara umum contextual mengandung arti: yang berkenaan, relevan, ada hubungannya atau kaitan langsung, mengikuti konteks; yang membawa maksud, makna dan kepentingan.
Menurut
Depdiknas
(2003:

"Kontekstual (Contextual Teaching and Learning) adalah konsep belajar yang membantu guru mengaitkan antara materi yang diajarkan dengan situasi dunia nyata dan mendorong siswa membuat hubungan antara pengetahuan yang dimilikinya dengan perencanaan dalam kehidupan mereka sehari-hari ".

Pendekatan CTL diharapkan lebih bermakna bagi siswa. Proses pembelajaran berlangsung alamiah dalam bentuk kegiatan siswa bekerja dan mengalaminya. Dalam konteks itu, siswa perlu mengerti apa makna belajar, apa manfaatnya, dalam status apa mereka, dan bagaimana mencapainya. Mereka sadar bahwa yang mereka pelajari berguna bagi kehidupannya nanti. Dalam kelas kontekstual, guru berusaha membantu siswa mencapai tujuan. Maksudnya guru lebih bannyak berurusan dengan strategi daripada memberi informasi. Tugas guru adalah mengelola kelas sebagai sebuah tim yang bekerja bersama untuk menemukan pengetahuan dan ketrampilan yang baru bagi siswa. Pengetahuan dan ketrampilan diperoleh dengan menemukan sendiri bukan apa kata guru.

"Guru memberikan kesempatan kepada siswa untuk menemukan atau menerapkan sendiri ide-ide dan mengajak siswa agar dengan menyadari dan dengan sadar menggunakan strategi-strategi mereka sendiri untuk 
belajar. Guru memberi siswa tangga yang dapat membantu siswa mencapai tingkat pemahaman yang lebih tinggi, namun harus diupayakan agar siswa sendiri yang memanjat tangga tersebut (Depdiknas, 2002: 4).

CTL adalah suatu strategi pembelajaran yang menekankan pada proses keterlibatan siswa secara penuh untuk dapat menemukan materi yang dipelajari dan menghubungkannya dengan situasi kehidupan nyata sehingga mendorong siswa untuk dapat menerapkannya dalam kehidupan mereka. Dari konsep diatas terdapat tiga hal yang harus kita pahami:

Pertama: CTL menekankan kepada proses keterlibatan siswa untuk menemukan materi, artinya proses belajar dioryentasikan pada proses pengalaman secara langsung.

Kedua: CTL mendorong agar siswa dapat menemukan hubungan antara materi yang dipelajari dengan situasi kehidupan nyara, artinya siswa dituntut untuk dapat menagkap hubungan antara pengalaman belajar di sekolah dengan kehidupan nyata. Hal ini sangat penting, sebab dengan dapat mengorelasikan materi yang ditemukan dengan kehidupan nyata, bukan saja bagi siswa materi itu akan berfungsi secara fungsional, akan tetapi materi yang dipelajarinya akan tertanam erat dalam memori siswa, sihingga tidak akan mudah dilupakan.

Ketiga: CTL mendorong siswa untuk dapat menerapkannya dalam kehidupan, artinya CRL bukan hannya mengharapkan siswa dapat memahami materi yang dipelajarinya, akan tetapi bagaimana materi pelajaran itu dapat mewarnai perilakunya dalam kehidupan sehari-hari.

Sehubungan dengan hal itu, Terdapat beberapa karakterristik dalam proses pembelajaran yang menggunakan pendekatan CTL yakni :

1. mengkaitkan bahan pelajaran dengan situasi dunia nyata

2. mendorong siswa menghubungkan yang dipelajari dengan kehidupan sehari-hari, pengalaman sesungguhnya dan penerapannya / manfaatnya

3. strategi: authentic, inkuiri, praktek kerja, pemecahan masalah

\section{Prinsip CTL}

1. Constructivism bisa diartikan bahwa siswa perlu dikondisikan untuk terbiasa memecahkan masalah, menemukan hal-hal yang berguna bagi dirinya dan bergelut dengan gagasangagasan

2. Inquiry adalah proses pembelajaran didasarkan pada pencapaian dan penemuan melalui proses berfikir secara sistematis.
3. Questioning berarti belajar pada hakekatnya adalah bertanya dan menjawab pertanyaan

4. Learning community, artinya bahwa pembelajaran diperoleh melalui kerjasam dengan oranglain

5. Modeling: proses pembelajaran dengan memperagakan sesuatu sebagai contoh yang dapat ditiru oleh setiap mahasiswa.

6. Authentic assessment, penilaian authentic yang dilakukan secara terintegrasi dengan proses pembelajaran dan dilakukan secara terus menerus selama kegiatan pembelajaran.

7. Reflection adalah cara berfikir tentang apa yang baru dipelajari atau berfikir ke belakang tentang apa yang sudah dilakukan di masa lalu.

\section{METODE PENELITIAN}

Penelitian ini dilakukan di Jurusan Pendidikan Antropologi universitas Negeri Medan. Penelitian diarahkan untuk memberikan pemahaman kepada mahasiswa dalam hubungannya dengan pariwisata meliputi wisatawan itu sendiri, hubungan antara wisatawan dengan masyarakat local, struktur dan fungsi system pariwisata dan dampak-dampak pariwisata, sehingga mahasiswa bisa berpikir dengan kritis tentang banyak hal.

\section{Tindakan}

Penelitian ini direncanakan dalam dua siklus. Adapun masing-masing siklus memuat empat rangkaian yang meliputi: Perencanaan, tindakan, pengamatan, dan refleksi. Berkaitan dengan ini, maka keempat bagian tersebut dijabarkan dalam penjelasan sebagai berikut:

1. Perencanaan

a. Pre Test

Pre test diberikan dengan menyajikan soal analisa kasus kepada peserta didik. Langkah ini dilakukan untuk mengetahui pengetahuan dan pemahaman peserta didik mengenai Antropologi Pariwisata. Hasil pre test, sekaligus menjadi data awal untuk memetakan pemahaman peserta didik sekaligus mengetahui kemampuan terhadap materi. Nilai yang didapatkan dari hasil pre test, akan dibandingkan dengan hasil post test setelah dilakukan tindakan melalui penerapan pendekatan kontekstual.

b. Penjelasan Pelaksanaan

Perencanaan diawali dengan pemilihan materi didasarkan pada konteks yang mengarahkan peserta didik untuk terjun ke lapangan. Jadi tidak semua materi dapat terambil dan dijadikan pelajaran yang bersifat observasi langsung dan wawancara. Di antara materi yang terpilih adalah:

1. Objek Wisata Istana Maimoon dan Masjid Raya Al Maksum sebagai Identitas Pariwisata Medan, 
2. Jalan Kesawan dan Gedung-gedung Tua Peninggalan Bersejarah Di Kota Medan,

3. Masjid Agung, Vihara Gunung Timur, Vihara Borobudur dan Kuil Sri Mariaman sebagai Kawasan Wisata Religi;

4. Travel Biro dan Perjalanan dalam Kemajuan Pariwisata di Medan,

5. Peranan Pemerintah Dalam usaha Memajukan Kepariwisataan di Medan,

6. Peranan Masyarakat Medan dalam Kepariwisataan.

Untuk dapat melakukan aktivitas pembelajaran, peserta didik dibagi ke dalam kelompok (satu kelompok terdiri dari tujuh orang) Setelah materi dibagikan kepada peserta didik. Ketujuh materi tersebut, dibagikan berdasarkan kelompok mahasiswa yang ada. Materi itulah yang akan menjadi acuan bagi peserta didik, untuk melakukan penelitian singkat di lapangan.

Peserta didik kemudian diarahkan untuk membentuk kelompok penelitian yang terdiri dari ketua dan anggota. Setelah itu, mereka diarahkan untuk mengambil satu pokok permasalahan berdasarkan materi yang diberikan. Kemudian diarahkan untuk membuat penelitian singkat yang dibuat dalam bentuk laporan yang terdiri dari: latar belakang masalah, rumusan, tujuan, kajian pustaka, metode penulisan, pembahasan, dan kesimpulan. Hasil penelitian hanya dibatasi maksimal 20 halaman spasi 1,5. Hasil penelitian tersebut dikumpulkan pada akhir perkuliahan sebagai togas akhir kelompok, sekaligus materi penilaian. Namun demikian, sepanjang kegiatan perkuliahan selama satu semester, peserta didik melaporkan hasil penelitian setiap minggu, sekaligus melaksanakan bimbingan dengan dosen yang bersangkutan.

Dengan demikian, perkuliahan di kelas tetap berlangsung secara aktif untuk memberikan bimbingan atas permasalahan yang ditemukan pada saat penelitian lapangan. Segala permasalahan yang berkaitan dengan konsep atau teori diberikan secara mendalam di kelas. Dengan model yang semacam ini, setiap kelompok dapat berkonsentrasi dengan materi masingmasing, sehingga penelitian mereka menjadi lebih fokus. Hal ini juga untuk mendapatkan kekhususan pengetahuan sekaligus variasi penemuan, jika sudah dipresentasikan di kelas.

Jadwal perkuliahan yang secara efektif berlangsung selama 16 kali pertemuan, yang dipecah menjadi 4 bentuk kegiatan perkuliahan, yakni: a. penyampaian materi : 5 kali pertemuan

b. penelitian, bimbingan dan book Review: 7 kali pertemuan

c. presentasi hasil penelitian: 3 kali pertemuan

2. Tindakan

d. ke objek wisata dan laporan akhir: 1 kali pertemuan

Pelaksanaan penelitian dilakukan dalam dua tahap. Setelah masing-masing kelompok mendapatkan materi, mereka kemudian dibimbing untuk terjun ke lapangan dalam melakukan observasi langsung dan wawancara. Peserta didik dibolehkan memilih lokasi masing-masing, sesuai dengan materi yang dipilihkan. Selama empat minggu pertama dalam tahap penelitian, peserta didik diharuskan membuat laporan penelitian tahap 1. Dengan demikian dalam tahap ini, mereka diharuskan sudah mempunyai pemahaman awal mengenai materi yang diberikan.

Setelah laporan hasil diserahkan kepada dosen, selanjutnya dilakukan test tahap I untuk mengetahui kemampuan berdasarkan pemahaman materi yang diberikan supaya soal yang diberikan tidak menyimpang dari materi. Test diberikan dalam bentuk analisa kasus berdasarkan materi masing-masing. Dengan demikian, dosen akan melihat perkembangan pemahaman peserta didik pada materi yang dipilihkan. Nilai hasil test akan menjadi bahan perbandingan untuk test tahap, setelah laporan tahap II selesai dengan sempurna.

3. Pengamatan

Pengamatan dilakukan terhadap aktivitas peserta didik di lapangan. Dosen memantau sejauh mana peserta mampu melakukan interaksi dengan masyarakat dalam rangka memahami kepariwisataan dari sudut pandang antropologi. Selain itu, pengamatan secara langsung mengenai hasil belajar dilakukan juga terhadap hasil observasi dan wawancara. Ukuran pemahaman kepariwisataan dari sudut pandang antropologi, terlihat pada proses pewacanaan yang dibuat oleh peserta didik dari hasil pengamatan dan wawancara.

4. Refleksi

Refleksi dilakukan pada akhir tiap-tiap siklus, hal ini dilakukan untuk melihat perkembangan peserta didik dalam menggali data di lapangan. Selain itu, refleksi juga diberikan pada akhir presentasi hasil penelitian. Dua pola: terjun ke lapangan dan presentasi adalah cerminan sejauh mana peserta didik dalam memahami kepariwisataan dari sudut pandang antropologi. Tingkat pemahaman mereka menjadi tolak ukur dalam mengukur dalam berfikir kreatif pada mahasiswa yang akan 
diberikan juga dalam bentuk test. Pada akhir perkuliahan, dosen memberikan test dalam bentuk pemecahan masalah yang digunakan untuk mengukur tingkat pemahaman siswa terhadap materi yang diberikan.

\section{HASIL DAN PEMBAHASAN}

\section{Bentuk Disain Pembelajaran Kontekstual Dan PENERAPANNYA PADA KaJIAN ANTROPOLOGI PARIWISATA}

Pandangan dalam proses pembelajaran di kelas paada umumnya memamndang peserta didik menerima pengetahuan secara pasif dari dosennya. Pandangan ini tidak seharusnya terus dilaksanakan dalam proses pembelajaran di tingkat universitas.

Pendekatan kontekstual adalah suatu konsep belajar yang mendorong partisipasi aktif dari peserta didik dengan menghubungkan materi yang sedang dipelajari dengan situasi nyata yang ada di lapangan. Bentuk pembelajaran kontekstual diantaranya:

1. Membuat hubungan-hubungan yang berarti (meaningful)

Dalam hal ini, mahamahasiswa mampu menghubungkan materi pembelajaran yang dipelajari dengan apa yang dihadapi dalam kehidupan sehari-hari untuk menemukan sesuatu yang lebih berarti, dan itulah arti hidup.

2. Mengerjakan pekerjaan yang bermakna (signifikan)

Pembelajaran harus mampu mengajak mahamahasiswa untuk melakukan segala sesuatu yang bernilai bagi dirinya, baik dari sudut nilai keilmuan dan/atau nilai praktis.

3. Belajar dengan ditata/diatur oleh dirinya sendiri (self regulated learning)

Mahamahasiswa memiliki kebebasan untuk menentukan, memutuskan, memilih apa yang ia pelajari sehingga ia dapat belajar dengan seoptimal mungkin sesuai dengan minat, bakat, dan kemampuannya. Dengan demikian, setiap mahamahasiswa benar-benar independen/tidak bergantung pada orang lain. Inilah yang masih sukar untuk dipenuhi jika pembelajaran dilakukan dalam bentuk klasikal yang secara otomatis menganggap mahamahasiswa yang manapun sama kondisinya. Dalam kegiatan kerja kelompok pun seharusnya ada kejelasan apa yang dikerjakan/dikontrubusikan oleh setiap individu mahamahasiswa, termasuk kontribusi untuk berpikir bersama, melakukan tugas tertentu bersama, tetapi tidak semuanya bersama sehingga tidak jelas apa yang dikerjakan orang perorang.

4. Berpikir kritis

Berpikir kritis berarti mahasiswa harus dapat memisahkan mana yang benar, mana yang salah, mana yang relevan, mana yang tidak relevan, mana yang positif, mana yang negatif. Untuk dapat berpikir kritis seseorang harus tahu: (a) apa sebenarnya isu nyata, masalah, atau keputusan yang dijadikan pertimbangan, (b) apa fokus masalahnya, (c) apa rasional untuk memecahkan masalah dan apakah rasional tersebut benar, (d) apa asumsi yang dipakai sebagai dasar, (e) apakah cara memaparkan sudah jelas, (f) apakah kesimpulannya benar, dan (g) apakah implikasinya jelas.

5. Berpikir kreatif

Berpikir kreatif berarti mampu menghasilkan ide/gagasan/pendapat/hal baru atau yang unik yang tidak terpikirkan oleh orang lain. Kendalanya adalah kepekaaan yang berbeda antar individu terhadap sesuatu, adanya perasaan takut salah, peraturan dan persyaratan yang terlalu mengikat, sikap tidak mau bertanya dan pasif untuk menerima, cara berpikir yang terkotak-kotak, tidak pernah berintuisi, takut berbuat salah, kurang waktu untuk melakukan refleksi. Pembimbingan secara individual (individual coaching). Dalam kegiatan pembelajaran setiap mahasiswa harus terlibat penuh di dalamnya sesuai dengan kemampuannya. Pembelajaran harus dapat memenuhi kebutuhan setiap mahasiswa dan mampu membelajarkan setiap mahasiswa sesuai dengan kemampuan awal, minat, bakat, kecepatan, dan langgam belajarnya. Namun pembelajaran juga bukan berarti seenaknya, melainkan harus dapat dipacu seoptiomal mungkin. Oleh karena itu, belajar harus maju bersangkutan orang perorang.

6. Berpikir konstruktivitik

Dalam belajar akan lebih bermakna jika mahasiswa bekerja sendiri untuk membangun pengetahuan baru atas dasar pengetahuan awal/pengalaman yang telah dimiliki. Dengan demikian, paradigma pembelajaran adalah "lebih penting bagaimana agar mahasiswa memiliki strategi untuk memperoleh sesuatu" daripada "seberapa banyak mahasiswa memperoleh sesuatu".

7. Menemukan (inquiry)

Dalam belajar, mahasiswa harus dilatih untuk menemukan hal baru (fakta, prosedur, konsep, prinsip). Dengan demikian, dalam belajar, seberapapun hal yang dipalajri sama sekali baru, sedapat mungkin harus ada yang ditemukan sendiri oleh mahasiswa.

8. Mengembangkan kemampuan bertanya

Belajar harus dimulai dari bertanya. Dengan demikian, diharapkan mahasiswa tahu apa yang ia tidak tahu.

Dalam mengembangkan desain pembelajaran berbasis CTL, dosen boleh memilih model pembelajaran yang bercirikan CTL, seperti model pembelajaran konstruktivisme, model pembelajaran penemuan (inquiry) yang dapat berupa penemuan terbimbing (guided inquiry) atau penemuan bebas (free inquiry), model pembelajaran lanjut dengan pengorganisasian pengetahuan awal (advance organizer), cara belajar mahasiswa aktif, pendekatan 
proses, problem base learning, authentic instruction, ataupun cooperative learning.

Model Pembelajaran yang dilakukan dalam mata kuliah Antropologi Pariwisata adalah pengorganisasian pengetahuan awal (advance organizer). Fase pembelajaran dalam model ini yaitu:

\section{Fase penyajian organizer}

Berupa kegiatan penyampaian organisasi pengetahuan awal (informasi awal) yang dapat menjadi intelectual scaffolding (kerangka intelektual) antara pengalaman mahasiswa dan konsep dari materi yang akan dipelajari dengan pemberian apersepsi tentang pentingnya materi yang akan dibahas, penyadaran kepada mahasiswa untuk menghubungkan materi yang dibahas dengan pengetahuan awal mahasiswa secara kontektual dengan memberikan contoh contoh/ fakta yang berhubungan dengan materi yang akan dibahas; jika sebagai sesuatu yang baru disertai dengan penjelasan verbal atau kutipan dari beberapa buku tentang konsep dari materi yang dibahas. Dosen memberikan arahan tentang proses pembelajaran dan luaran yang diharapkan yaitu setiap mahasiswa mampu menuangkan pengembangan gagasannya terhadap permasalahan perkembangan pariwisata di Sumatera Utara dalam hal ini kota Medan dalam bentuk artikel ilmiah.

\section{Fase penyajian informas}

Berupa kegiatan untuk mengkaji berbagai informasi yang berkait dengan konsep dari materi yang dibahas, termasuk menyelesaikan tugas-tugas yang berkaitan dengan konsep dari materi yang dibahas, dosen mengorganisasi seluruh kegiatan agar informasi yang ingin dicari dapat diperoleh mahasiswa. Pengumpulan informasi melalui pembacaan buku (CBR) dan artikel yang terpublikasi (CJR) membantu mahasiswa untuk menemukan berbagai permasalahan yang pernah terjadi terkait dengan pariwisata dan perkembangannya. Kegiatan mini riset (kunjungan) ke berbagai objek wisata juga membantu mahasiswa melihat secara langsung permasalahan permasalahan yang dihadapi pariwisata di kota Medan.

3. Fase menghubungkan organizer dengan presentasi

Berupa kegiatan menghubungkan organiser (pengetahuan awal mahasiswa) dengan berbagai informasi yang telah dipelajari. Pada tahapan ini mahasiswa menentukan rumusan permasalahan yang akan dibahas dalam artikel ilmiah yang akan dibuat. Lalu mahasiswa belajar menuangkan hasil mini risetnya terhadap objek objek wisata di kota Medan dan menuangkannya dalam bentuk tulisan (rekayasa ide).

\section{Fase aplikasi}

Fase ini dimunculkan dengan maksud melihat hubungan antara konsep yang dipelajari mahasiswa dengan ketrampilan sehingga akan dapat diketahui seberapa mampu mahasiswa mengaplikasikan teori ke dalam praktik.
Mahasiswa menyesuaikan tulisan yang telah dibuat dengan format artikel ilmiah pada salah satu jurnal di FIS.

\section{Penerapan Pendekatan Kontekstual dapat MenumbuhKan Daya Berfikir Kritis PADA MAHASISWA}

Daya berfikir kritis pada mahasiswa merupakan hasil yang diharapkan untuk melahirkan generasi yang kreatif dan maju. Penerapan pembelajaran kontekstual yang diterapkan di kelas Antropologi Pariwisata menunjukkan adanya daya berfikir kritis pada mahasiswa hal tersebut dibuktikan dengan munculnya berbagai ide yang dituangkan dalam artikel ilmiah yang dibuat serta pandangan kritis terhadap permasalahan perkembangan pariwisata yang dihadapi oleh kota Medan.

Penerapan pembelajaran kontekstual bukanlah suatu yang mudah untuk diterapkan di tengah mahasiswa yang memiliki kebiasaan meneliti dan menulis kurang. Untuk dapat menumbuhkan daya berfikir yang kritis pada mahasiswa dalam mata kuliah Antropologi Pariwisata maka pendekatan kontekstual yang dilakukan membutuhkan perangkat penugasan yang mampu memberikan rangsangan berfikir kritis.

Enam penugasan yang dirangkai kedalam setiap fase mampu memberikan rangsangan terhadap berfikir kritis mahasiswa. Namun demikian ada beberapa faktor yang ditemukan menjadi penghambat rangsangan diantaranya kesulitan mahasiswa menghadapi enam penugasan dari mata kuliah lain. Pengelolaan enam penugasan yang benar dan tepat akan membantu mahasiswa menghadapi berbagai kendala yang ditemukan dalam menyelesaikan penugasan yang diterima dari berbagai mata kuliah. Sehingga dalam mata kuliah ini penugasan yang berkaitan dengan mini riset dikolaborasi dengan mata kuliah lain seperti Antropologi Lingkungan dan Antropologi Pedesaan.

Pendekatan kontekstual pada mata kuliah Antropologi Pariwisata ini tidak hanya mampu menumbuhkan berfikir kritis mahasiswa terhadap berbagai kendala yang dihadapi pariwisata di kota Medan namun juga mampu merangsang kreatifitas mahasiswa dalam mengembangkan pariwisata di kota Medan.

Beberapa kelompok mahasiswa bahkan mampu menghubungkan permasalahan pariwisata dengan kegiatan dalam komunitasnya. Prodi. Pendidikan Antropologi memiliki komunitas mahasiswa yang membentuk kelompok bisnis mahasiswa di bidang industri kreatif. Beberapa mahasiswa yang mengikuti mata kuliah ini merupakan anggota komunitas tersebut. Komunitas bisnis mahasiswa yang bergerak di bidang industri keratif ini pada awalnya hanya memproduksi produk dari daerah pesisir. Setelah mereka mengikuti fase pertam dan kedua muncul ide untuk menghasilkan produk yang berkaitan dengan pariwisata dan kebudayaan, berupa rumah adat, kapal tradisional, dll. 


\section{PENUTUP}

Pembelajaran kontekstual dalam pembelajaran mata kuliah Antropologi Pariwisara mampu meningkatkan berfikir kritis mahasiswa. Bentuk model pembelajaran kontekstual yang menerapkan enam penugasan membantu merangsang peningkatan berfikir kritis mahasiswa.

Penerapan pembelajaran kontekstual tidak hanya sekedar merangsang berfikir kreatif yang ditunjukkan dalam tulisan atau rekayasa ide namun juga merangsang ide kreatif mahasiswa yang dimplementasikan dalam kegiatan komunitas bisnis mahasiswa.

\section{DAFTAR PUSTAKA}

Arikunto, Suharsimi, et.al. 2007. Penelitian Tindakan Kelas. Jakarta: Bumi Aksara.

Causey. Andrew. 2006. Danau Toba: Pertemuan Wisatawan Dengan Batak Toba dipasar Suvenir. Medan: Bina Media.

Cultural Studies. Teori dan Praktek: Jakarta: Kreasi Wacana. Skober, Tanti., 1993. Nuansa Kampung Halaman., Jakarta: Puspa Swara.

Dominiguez. 1987. The Marketing of Herritage

Kincaid., J. 1989. A Small Place. New York: Plume.

Kirshenblatt-Gimblett, B. 1998. Destination Culture: Tourism, Museum and heritage.

Komalasari, Kokom. 2007. Peningkatan Berfikir Kritis Siswa dalam PKn Melalui Penerapan Model Controversial Issues. dalam Setiawan, Deny, Samsuri et.al. Seminar Nasional Pendidikan Ilmu Sosial "Revitalisasi Ilmu Pengetahuan Sosial Dalam Perspektif Global" 21 November 2007. Bandung: Universitas Pendidikan Indonesia.

Komalasari, Kokom. 2010. Pembelajaran Kontekstual: Konsep dan Aplikasinya. Bandung: Refika Aditama.

MacCannel, D, 1976. The Tourist: A New Theory of the leisure class.

\section{Experiences.}

Miles, MB and Hubberman, AM Qualitative Data Analysis: A Sourcebook of News Method, Beverly Hills, CA: Stage Publication, 1984.

Picard, Michel. 2006. Bali: Pariwisata Budaya clan Budaya Pariwisata. Jakarta: KPG dan EFEO

Pitana, I Gde dan Putu G. Gayatri. 2005. Sosiologi Pariwisata. Yogyakarta: Andi Offset.

Rachmah, Huriah. 2007. Peranan Guru Dalam Mengembangkan Sikap Berfikir Kritis Siswa, dalam Setiawan, Deny, Samsuri et.al. Seminar Nasional Pendidikan Ilmu Sosial "Revitalisasi Ilmu Pengetahuan Sosial Dalam Perspektif Global" 21 November 2007. Bandung: Universitas Pendidikan Indonesia.

Ritauw, Samuel Patra. 2007. Strategi Pembelajaran Contextual Teaching and Learning dalam Pembelajaran IPS, dalam Setiawan, Deny, Samsuri et.al. Seminar Nasional Pendidikan Ilmu Sosial "Revitalisasi Ilmu Pengetahuan Sosial
Dalam Perspektif Global" 21 November 2007. Bandung: Universitas Pendidikan Indonesia.

Rogers, Mary F. 2003 Barbie Culture: Ikon Budaya Konsumerisme. Jakarta: bentang. Barker., Chris. 2004.

Spradley, James P. 2007. Metode Ethnografi. Yogyakarta: Tiara Wacana.

Stanley, Nick. 1998. Being Ourselves for you: The Global Diplay of Cultures.

Urry, J. 1990. The Tourist gaze: Leisure and Travel in Contemporary Societies.

WTO (World Tourism Organization). 1995. Technical manual No. 1, Concept, definition and Classification for tourism Statistic. Madrid. 